\title{
Assessment of the genotoxic and antigenotoxic potential of crude extracts and fractions of Schwartzia brasiliensis (Choisy) Bedell ex Giraldo-Cañas
}

\author{
Mello G. S. ${ }^{1}$, De Mattos J. C. P. ${ }^{2}$, Amaral A. C. F. ${ }^{3}$, Amorim L. M. F. ${ }^{4}$, Caldeira-de-Araujo A. ${ }^{2}$ \\ and Albarello N. ${ }^{{ }^{*}}$
}

${ }^{1}$ Laboratório de Biotecnologia de Plantas, Departamento de Biologia Vegetal, Instituto de Biologia Roberto Alcantara Gomes, Universidade do Estado do Rio de Janeiro (UERJ), Rua São Francisco Xavier, n. 524, sala 509, 20.550-013, Rio de Janeiro, Brasil.

${ }^{2}$ Laboratório de Radio e Fotobiologia, Departamento de Biofísica e Biometria, Instituto de Biologia Roberto Alcantara Gomes, Universidade do Estado do Rio de Janeiro (UERJ), Avenida 28 de setembro, n. 87, 4². Andar, 20551-030, Rio de Janeiro, Brasil.

${ }^{3}$ Laboratório de Produtos Naturais 1, Instituto de Tecnologia em Fármacos - Far-Manguinhos/FIOCRUZ, Rua Sizenando Nabuco, n. 100, 21041-250, Rio de Janeiro, Brasil.

${ }^{4}$ Laboratório de Oncologia Molecular, Departamento de Biologia Celular e Molecular, Universidade Federal Fluminense (UFF), Rua Outeiro de São João Batista s/n., 24020-150, Niterói, Brasil.

Received 15 December, 2014; Accepted 12 February, 2015

\begin{abstract}
Schwartzia brasiliensis (Marcgraviaceae) is a native Brazilian shrub species with neotropical distribution in shoal environments. Recent studies have revealed its medicinal potential for some human diseases; therefore, this study aimed to evaluate the genotoxic and antigenotoxic potential of extracts and fractions obtained from different organs of $S$. brasiliensis. To accomplish this, plant extracts at different concentrations $(25,125$ and $250 \mu \mathrm{g} / \mathrm{ml})$ were incubated with plasmid DNA, either alone, or in the presence of stannous chloride as a positive control. Samples were then examined to detect any plasmid strand breaks or the absence of such breaks, which would indicate protection of these molecules against stannous chloride-induced lesions. Methanol and aqueous extracts of leaves and stems showed the ability to withstand the effects of stannous chloride in that no DNA damage was observed. Moreover, no other extracts or fractions used in the experimental conditions assayed resulted in DNA damage. These findings suggest that $S$. brasiliensis has antigenotoxic properties, indicating, in turn, that its biological activities deserve further study given the medicinal relevance of this plant.
\end{abstract}

Key words: Medicinal plant, Marcgraviaceae, stannous chloride, flavonoids.

INTRODUCTION

Medicinal plants and their derivatives have been used as important sources of biologically active substances
(Newman and Craag, 2012) that are known to promote health, treat illness, and cure, or prevent many diseases 
(Efferth and Grefen, 2014; Gurib-Fakim, 2006; Jachak and Saklani, 2007). Such phytomedicines are usually alternative or complementary options to treatments with synthetic drugs (Dragan et al., 2015; Olasehinde et al., 2014). However, even though considered therapeutic, some bioactive plant derivatives may have toxic properties that will cause damage to the human organism, including the induction of genetic damage (Bednarczuk et al., 2010; Düsman et al., 2012; Efferth and Grefen, 2012).

Schwartzia brasiliensis belongs to the Marcgraviaceae family, and it is found in shoal environments of the Brazilian Atlantic Forest. This is a shrub species whose flowering takes place in summer (Ferreira, 1995; Zamith and Scarano, 2004) and whose conspicuous inflorescences might be used for ornamental purposes. $S$. brasiliensis also presents nectaries to attract bird pollinators (Rocca et al., 2006; Rocca and Sazima, 2008). Initially, the species was included in the Norantea genus (Giraldo-Cañas, 2004), but it now belongs to the Schwartzia genus. Pharmacological studies with some species of the Marcgraviaceae family indicate antifungal (Jones et al., 2000) and anxiolytic activities (Mullally et al., 2011). Studies investigating the medicinal potential of S. brasiliensis also reported antibacterial activities (Mello et al., 2014), and Agripino et al. (2004) showed that ethanol extracts of stems of $S$. brasiliensis could protect against DNA damage. In folk medicine, $S$. brasiliensis tea is used to prevent heart disease (Agra, 2008), but no scientific studies have shown either efficacy or safety. In this context, the present work aims to evaluate the genotoxic and antigenotoxic potential of crude extract and different fractions of $S$. brasiliensis grown in a natural environment.

\section{MATERIALS AND METHODS}

\section{Plant}

The plants were collected in the morning, around 10:00 a.m., in March, 2012, on a preserved sandbank area, located in Barra da Tijuca, Rio de Janeiro City, $22^{\circ} 59^{\prime} 29.7^{\prime \prime} \mathrm{S}$ to $43^{\circ} 20^{\prime} 48.4^{\prime \prime}$ W, Rio de Janeiro State, Brazil. The material was collected in vegetative stage under license from SISBIO/IBAMA number 3299651. A voucher (HRJ 11749) has been deposited in the Herbário da Universidade do Estado do Rio de Janeiro (HRJ).

\section{Preparation and fractionation of the extracts}

Leaf, stem and root samples of $S$. brasiliensis were fragmented, dried at $40^{\circ} \mathrm{C}$ for $24 \mathrm{~h}$, and added to methanol (MeOH) for 15 days at environmental conditions. The extracts obtained were filtered using Whatman paper $n^{\circ} .1$, evaporated at $40^{\circ} \mathrm{C}$ and concentrated in vacuum. Then, approximately $3 \mathrm{~g}$ of each crude extract were subjected to fractionation with different polarities of chemical solvents (n-hexane, ethyl acetate and distilled water). The fractions were evaporated at $40^{\circ} \mathrm{C}$ and concentrated in vacuum. Immediately before the use, both the crude methanol extracts and the fractions were solubilized and diluted in ultrapure water until reaching the concentrations required to carry out the experiments.

Evaluation of the genotoxic and antigenotoxic potential through agarose gel electrophoresis assay with plasmid DNA

Genotoxic and antigenotoxic potentials of S. brasiliensis were evaluated according to Caldeira-de-Araujo et al. (1996). This assay is based on the ability of the reducing agent stannous chloride $\left(\mathrm{SnCl}_{2}\right)$ to induce DNA strand breaks. During agarose gel electrophoresis, $\mathrm{SnCl}_{2}$-induced lesions can cause plasmid DNA conformational changes, leading to modification in migration pattern. Gel electrophoresis was performed in order to separate different conformations of plasmid DNA: native conformation (supercoiled or form I); open circle (or form II), resulting from singlestrand DNA breaks; and linear (or form III) generated through double-strand breaks.

The plasmid DNA used in this investigation was pUC 9.1, as maintained in $\mathrm{DH} 5 \mathrm{aF}$ 'IQ $E$. coli cells. The plasmidial molecules were purified from $\mathrm{DH} 5 \mathrm{\alpha F}$ 'IQ $E$. coli cultures, in stationary growth phase, according to the Invisorb $₫$ Spin Plasmid Mini Two (Invitek) protocol. In order to evaluate genotoxic and antigenotoxic potential, three different concentrations $(25,125$ and $250 \mu \mathrm{g} / \mathrm{ml})$ of each extract and fraction were incubated with $200 \mathrm{ng}$ of plasmid DNA in the presence, or not, of $\mathrm{SnCl}_{2}(200 \mu \mathrm{g} / \mathrm{ml})$. All dilutions were done in ultrapure water (Milli-Q system, EMD Millipore, Billerica, MA, USA, and the reaction mixtures were incubated for $40 \mathrm{~min}$ at room temperature. Then, aliquots of each sample $(10 \mu \mathrm{l})$ were mixed with $2 \mu \mathrm{l}$ of loading buffer $(0.25 \%$ xylene cyanol; $0.25 \%$ bromophenol blue; $30 \%$ glycerol in water), applied on agarose gel $(0.8 \%)$ in TAE $1 \mathrm{X}$ buffer and submitted to electrophoresis at $7 \mathrm{~V} / \mathrm{cm}$ for $30 \mathrm{~min}$. Afterwards, the gel was stained with ethidium bromide $(0.5 \mathrm{mg} / \mathrm{ml})$, and the DNA bands were visualized by fluorescence in an ultraviolet transilluminator system (UVP, LLC, Upland, CA, USA). Each experiment was repeated three times, and the best result was selected for presentation. The gel bands were then digitized, and the results obtained provide a qualitative analysis. A quantitative evaluation in Plasmid DNA conformational structure was also performed by using $\mathrm{NIH}$ Image J software.

\section{Statistical analysis of DNA strand breaks}

The data presented in Figure 1 were analyzed through densitometer scanning, and percentage of form I was used to obtain the average number of breaks per pUC 9.1 plasmid DNA molecule. According to Remington and Schor (1985), the Poisson distribution could be used to obtain the average number of breaks from the percentage of DNA supercoiled forms, as $\mu=-\ln p(0 ; \mu)$, Considering no breaks $=p(0 ; \mu)$. 
Analysis by high-performance liquid chromatography with diode-array detection (HPLC/DAD)

The analysis by HPLC/DAD was performed under the following conditions: Mode: isocratic ACN/aqueous $0.05 \%$ TFA (30:70) for 55 $\mathrm{min}$ and flow $0.5 \mathrm{ml} / \mathrm{min}$ in Shim-pack XR-ODS column $(100 \mathrm{~mm} \times$ $2.0 \mathrm{~mm}, 2.2 \mu \mathrm{m}$, Shimadzu). All injections were performed with a volume of $20 \mu \mathrm{l}$ loop. Detection was performed in the ultraviolet wavelengths of 254 and $325 \mathrm{~nm}$.

\section{RESULTS AND DISCUSSION}

In the present study, electrophoresis assay with plasmid DNA was used in order to evaluate both genotoxic and antigenotoxic properties of $S$. brasiliensis. Based on its genotoxic oxidative properties, which result in DNA strand breaks, stannous chloride $\left(\mathrm{SnCl}_{2}\right)$ was used as a positive control in this study. Thus, the incubation of $S$. brasiliensis extracts or fractions with plasmid DNA alone, or in combination with $\mathrm{SnCl}_{2}$, could provide the basis for determining genotoxic vs. antigenotoxic activity. In particular, alterations in plasmid DNA pattern migration through agarose gel in samples incubated with plant extracts or fractions could reflect the potential to promote DNA strand breaks. Conversely, the ability of samples to prevent damage to plasmid DNA caused by $\mathrm{SnCl}_{2}$ could also reflect the antigenotoxic potential of $S$. brasiliensis. This gel electrophoresis assay is fully described in De Mattos et al. (2004), and the assay has been applied elsewhere to other medicinal species (Simões et al., 2006; Biso et al., 2010; Hamedt et al., 2014). Moreover, since $\mathrm{SnCl}_{2}$ can induce reactive oxygen species, especially hydroxyl radicals (Caldeira-de-Araujo et al., 1996), the antioxidant properties of $S$. brasiliensis extracts or fractions could prevent DNA damage. However, a full assessment of this property is outside the scope of this paper.

Methanol extract of leaves was able to fully protect DNA against stannous chloride-induced damage, but only when tested at the concentration of $250 \mu \mathrm{g} / \mathrm{ml}$ (Figure $1 \mathrm{~A}$ ), as indicated in the control sample (form 1, lane 1) at $88.6 \%$ vs. $10.3 \%$ in lane 2 (pUC 9.1 plus $\mathrm{SnCl}_{2}$ ), and $85.4 \%$ when methanol extract of leaves was added (Figure 1A, lane 8).

Aqueous fraction of leaves also seems to possess an antigenotoxic effect because it was also able to reduce the level of DNA breaks induced by stannous chloride (Figure 1B; lanes 6, 7 and 8). Lane 7 presents $28.23 \%$ of plasmid molecules in form I (control native conformation), whereas lane 2 in the same figure shows only $18.78 \%$, supporting the antigenotoxic action of $S$. brasiliensis leaves in aqueous fraction. Both sets of results are based on assessment of the average number of breaks per genome (Figure 2A and B). The chromatograms obtained by High-performance liquid chromatography with photodiode array detection (HPLC/DAD) revealed that methanol extracts have the majority of signals with retention time values equal to 8.659 and $9.452 \mathrm{~min}$ (Figure $3 \mathrm{~A}$ ). Aqueous fraction showed a majority of signals with retention time equal to 8.710 and 9.570 (Figure 3B), being related to the chemical class of flavonoids. Phytochemical analysis of leaves of $S$. brasiliensis, according to Barbosa et al. (2004) showed the presence of phenolic compounds, mainly flavonoids (Mello et al., 2012).

The antigenotoxic effect of $S$. brasiliensis leaves may be related to their chemical constituents. Flavonoids are described as having antioxidant (Brunetti et al., 2013; Procházková et al., 2011; Romano et al., 2013) and antigenotoxic activities (Boubaker et al., 2013; Chaabane et al., 2012). In addition, flavonoids have antineoplastic effects and can also protect against cardiovascular and neurodegenerative diseases (Obrenovich et al., 2010; Obrenovich et al., 2011; Simões et al., 2006).

The methanol extract and aqueous fraction of stems of S. brasiliensis also revealed antigenotoxic potential (Figure $1 \mathrm{E}$ and $\mathrm{F}$, lane 8 ), as confirmed by evaluation of the average number of breaks per genome (Figure 2E and $\mathrm{F}$, lane 8). These data corroborate a previous study showing that the ethanol extract of stems is able to reduce DNA damage in Saccharomyces cerevisiae (Agripino et al., 2004).

In the present report, it was observed that the methanol extract and aqueous fraction of stems decreased DNA damage caused by $\mathrm{SnCl}_{2}$, suggesting a dose-dependent effect (Figure $1 \mathrm{E}$ and $\mathrm{F}$ ). This protective effect has already been observed elsewhere, using the same experimental approach, with extracts of Cleome rosea (Simões et al., 2006), Daphne gnidium (Chaabane et al., 2012) and Nitraria retusa (Boubaker et al., 2013). The chromatograms obtained from the methanol extract and aqueous fraction of stems, using the method proposed, were insufficient to determine their constituents accurately.

In the evaluation of genotoxic potential, the obtained data from methanol extract and aqueous fraction of stems show no DNA damage (Figure 1; lanes 3, 4 and 5), exhibiting instead, antigenotoxic properties. Although antigenotoxic effect was found in stem extracts, analyses of leaf extracts showed more promising results, justifying the choice of this organ for further phytochemical analysis. On the other hand, no antigenotoxic effect was shown for root extracts. This experimental approach has been used elsewhere in order to evaluate a genotoxic or antigenotoxic profile induced by different plant species (Biso et al., 2010; Ferreira-Machado et al., 2004; Hamedt et al., 2014). Therefore, the use of other study designs, both in vivo and in vitro, is necessary to ensure the safety and efficacy of $S$. brasiliensis as a medicinal plant. 
A
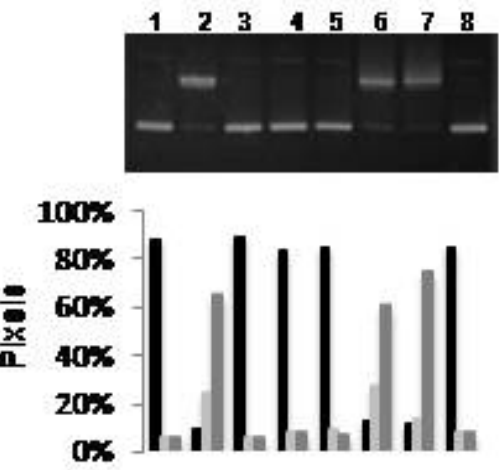

E)
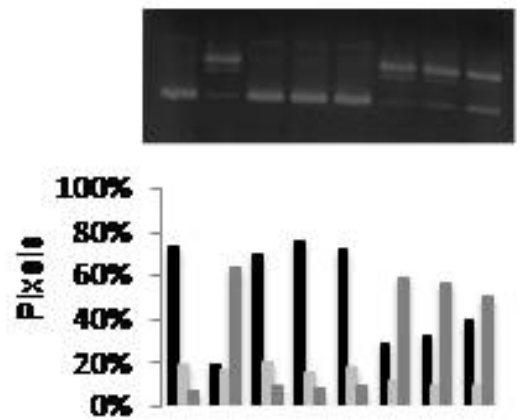

D
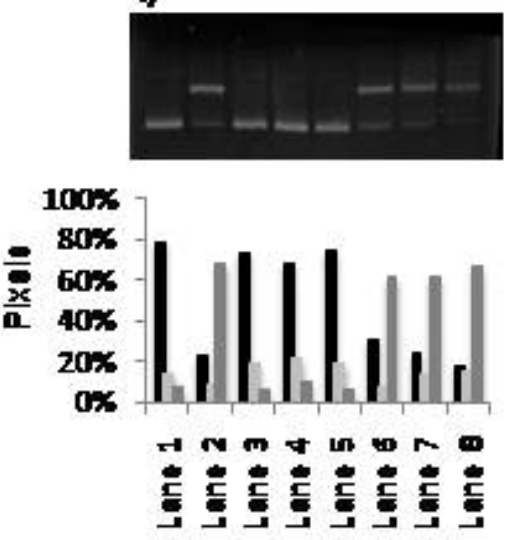

B)
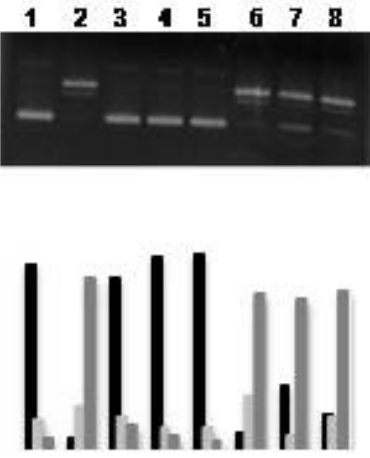

F)
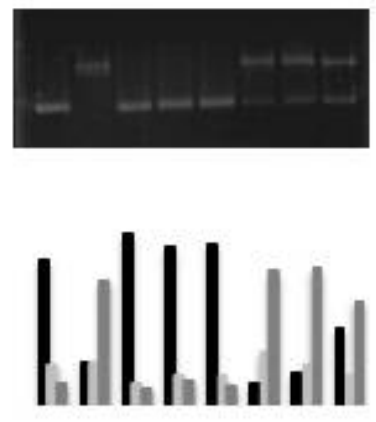

J)
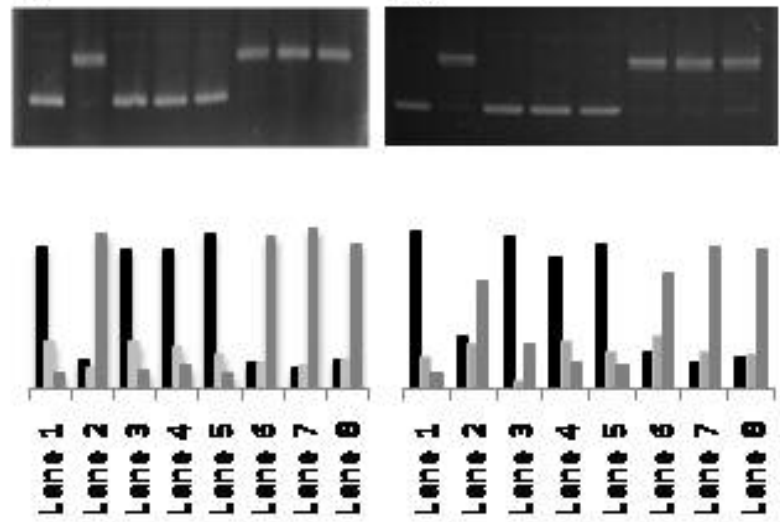

K)

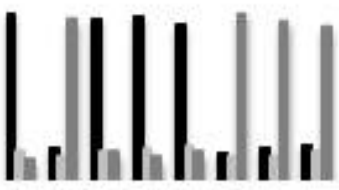

c)
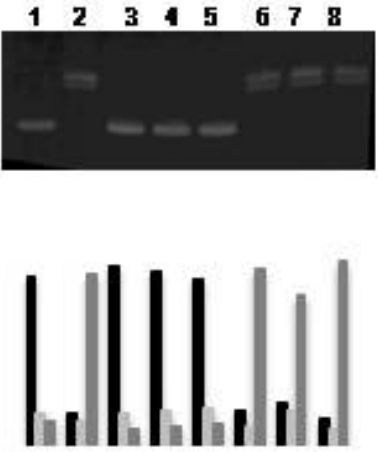

G)
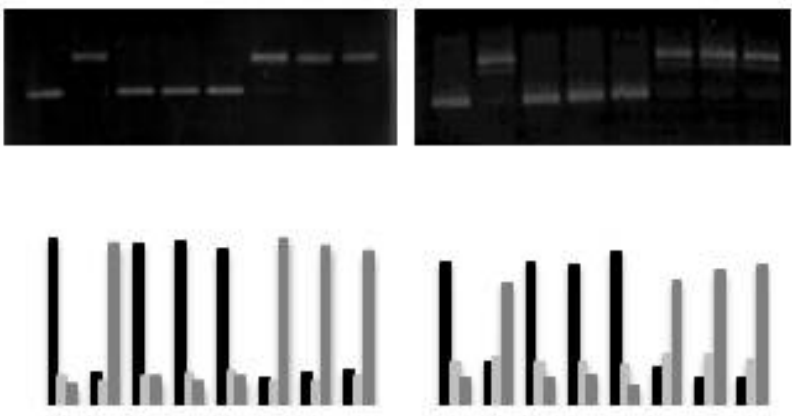

4

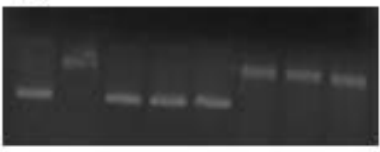

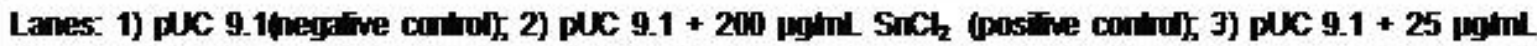

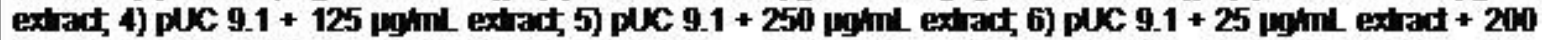

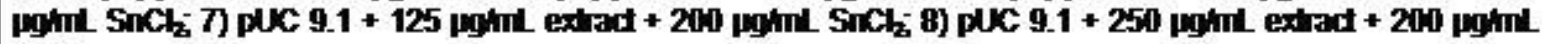
$\mathrm{SnCl}_{2}$

Graphics: Dupercoled Linear Opencide

Figure 1. Qualitative and quantitative analysis of the genotoxic and antigenotoxic potential of $S$. brasiliensis extracts and fractions on plasmid pUC 9.1 DNA bands corresponding to aliquots of the plasmid solution (200 ng) treated with extracts and fractions (25, 125 and $250 \mu \mathrm{g} / \mathrm{ml})$. A) methanol leaf extract; B) aqueous leaf fraction; C) n-hexane leaf fraction; D) ethyl acetate leaf fraction; E) methanol stem extract; F) aqueous stem fraction; G) n-hexane stem fraction; H) ethyl acetate stem fraction; I) methanol stem extract; J) aqueous root fraction; K) n-hexane root fraction; L) ethyl acetate root fraction. Bars represents DNA densitometric measures (\%) by image $\mathrm{J}$ 
A)

B)

C)

D)
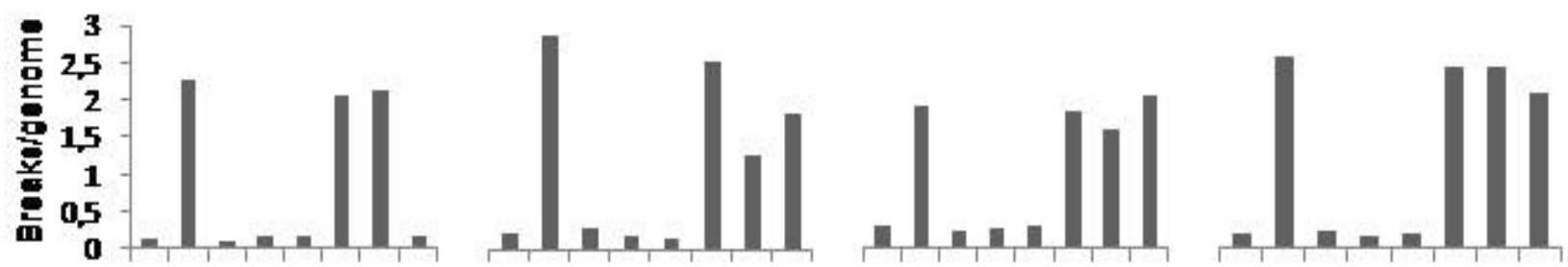

E)

F)

G)

H)
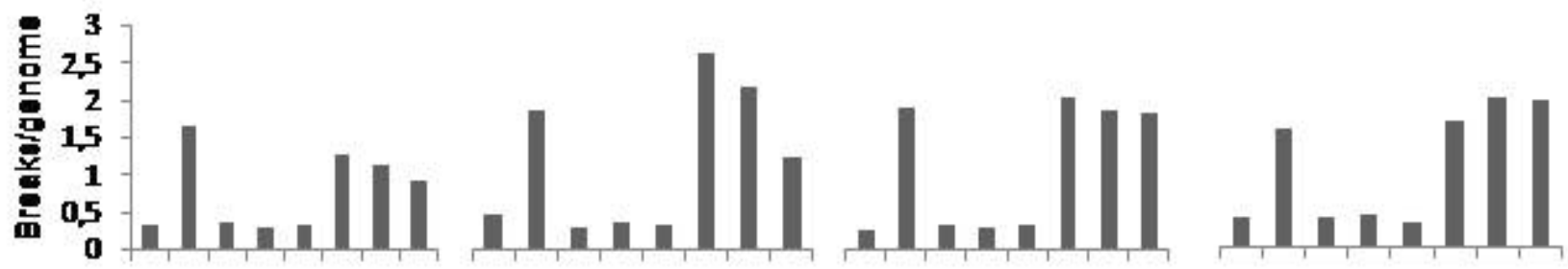

D)

J)

K)

L)
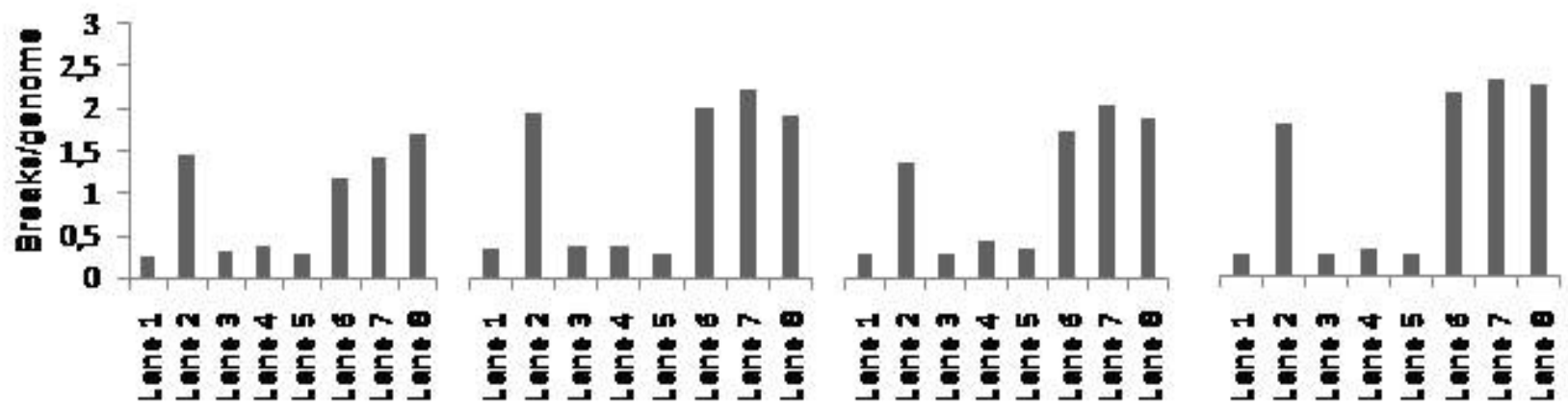

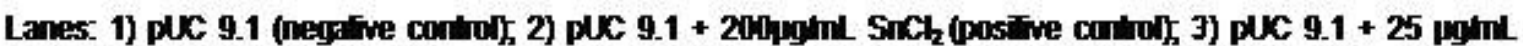
extact 4) pUK 9.1 + 125 pginl extract 5) pUK 9.1 + 250 pginl extact 6) pUK 9.1 + 25 pghl extract +

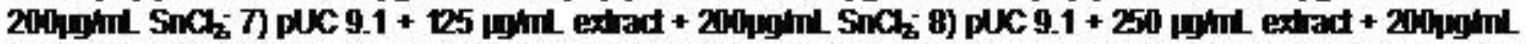
$\mathrm{SinC}_{2}$ Graphics: breakstgenome

Figure 2. Number of single strand breaks/genome in plasmid pUC 9.1 DNA treated with S. brasiliensis extracts and fraction. Lanes corresponding to aliquots of the plasmid solution $(200 \mathrm{ng})$ treated with the extracts and fractions $(25,125$ and 250 $\mu \mathrm{g} / \mathrm{ml}$ ). A) methanol leaf extract; B) aqueous leaf fraction; C) n-hexane leaf fraction; D) ethyl acetate leaf fraction; E) methanol stem extract; F) aqueous stem fraction; G) n-hexane stem fraction; H) ethyl acetate stem fraction; I) methanol stem extract; J) aqueous root fraction; K)n-hexane root fraction; L) ethyl acetate root fraction. Bars represents the number of single strand breaks/genome of three independent experiments. 
A)

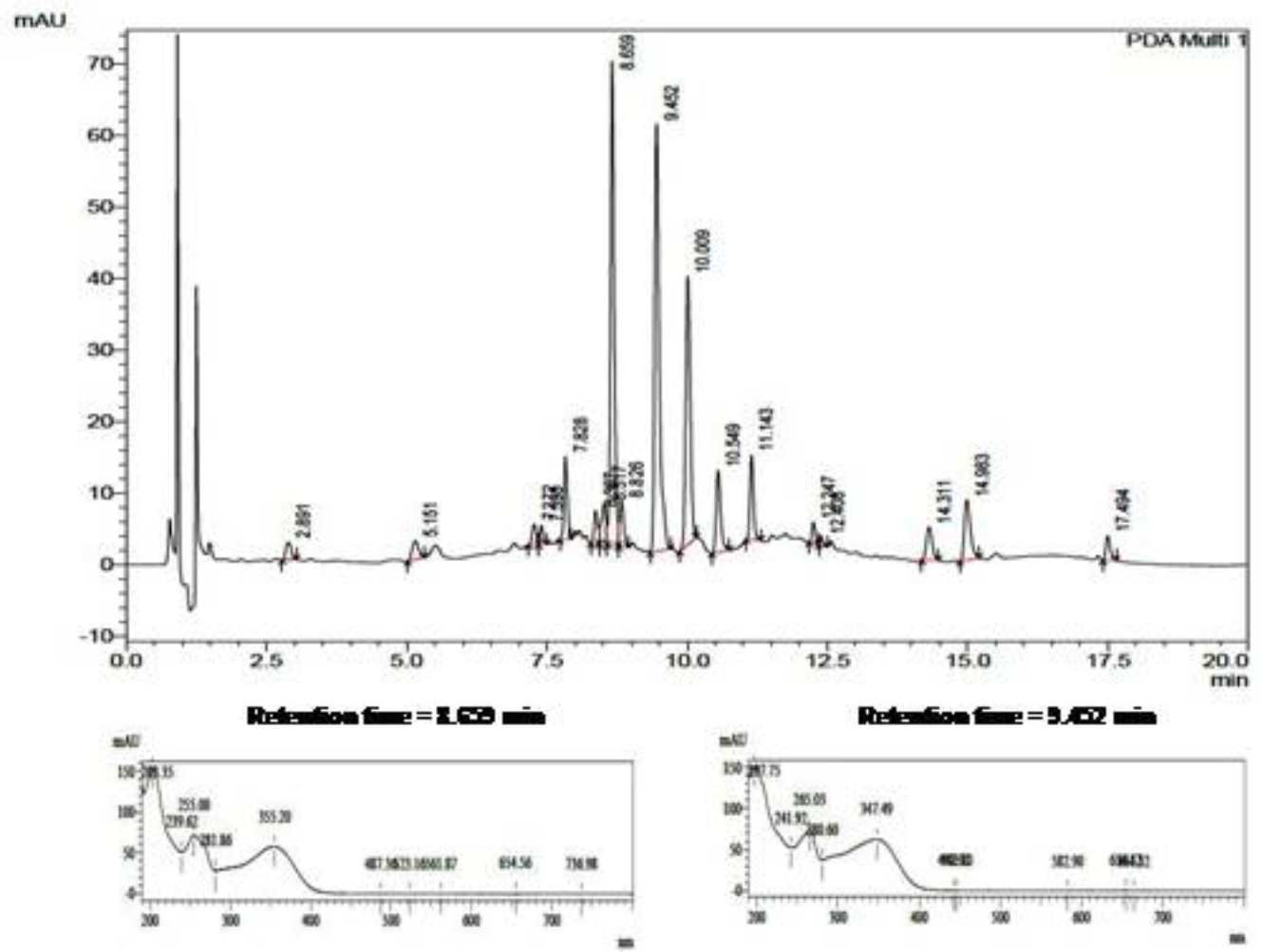

B)

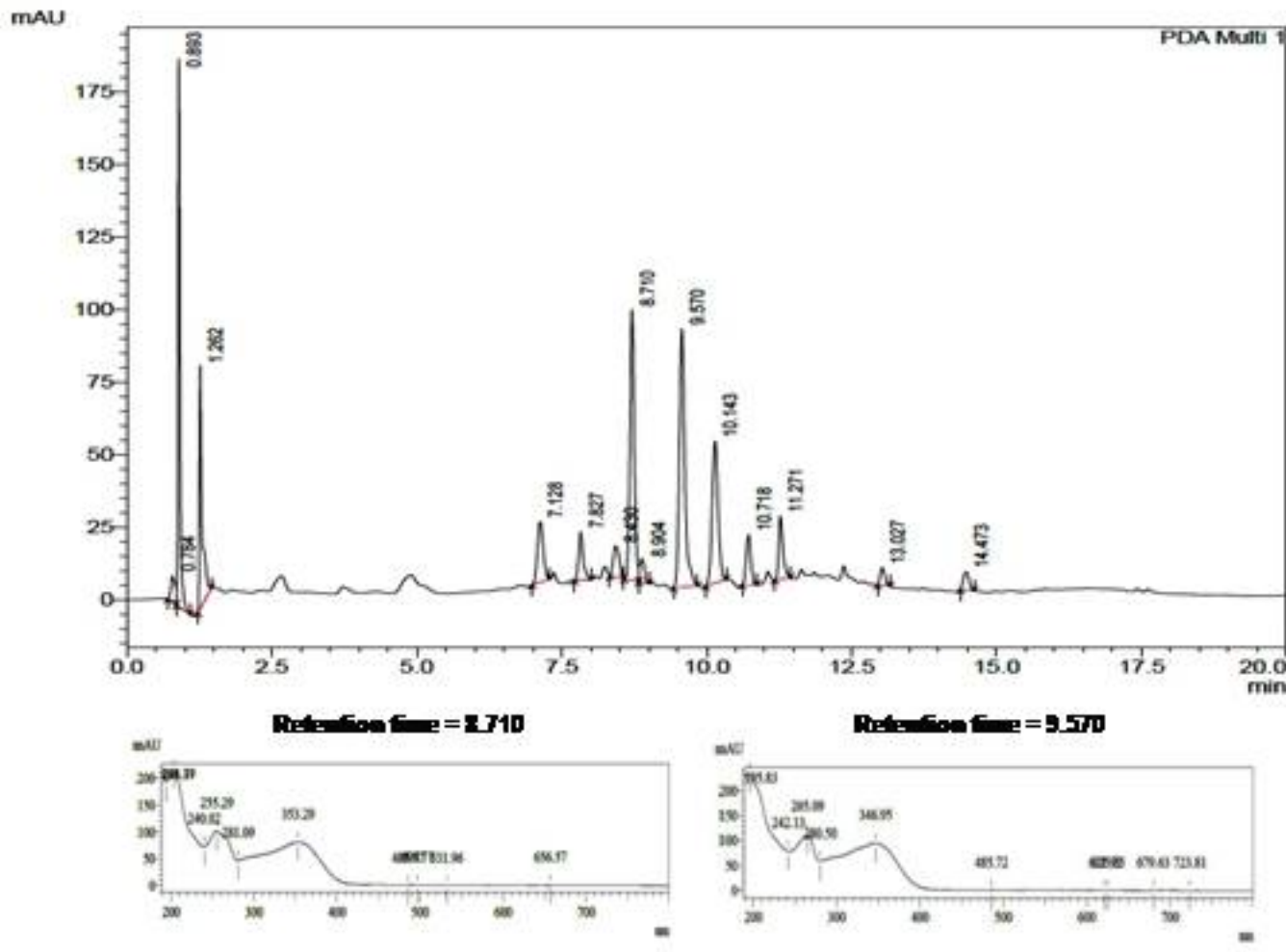

Figure 3. HPLC/DAD analysis of major compounds of methanol extract and aqueous fractions of S. brasiliensis in $254 \mathrm{~nm}$ and their absorption spectra in the ultraviolet region. A) methanol $\begin{array}{lllll}\text { leaf extract; } & \text { B) } & \text { aqueous } & \text { leaf } & \text { fraction. }\end{array}$ 
In conclusion, this work constitutes the first report on the genotoxic potential and antigenotoxic properties of $S$. brasiliensis. Results showed no genotoxic effect on DNA plasmid pUC 9.1. Moreover, it was shown that methanol and aqueous fractions of leaves and stems, at the highest concentration tested, have antigenotoxic activity protecting DNA from the breakdown caused by the stannous chloride. Considering the phytochemical profile obtained, we suggest that flavonoid content may be responsible for the activities evaluated.

\section{ACKNOWLEDGEMENTS}

The authors acknowledge the suggestions of Dr. Flávio J. Dantas and the financial support from Conselho Nacional de Desenvolvimento Científico e Tecnológico (CNPq), Coordenação de Aperfeiçoamento de Pessoal de Nível Superior (Capes) and Fundação de Amparo à Pesquisa do Estado do Rio de Janeiro (FAPERJ).

\section{Conflicts of Interest}

The authors declare that they have no conflicts of interest.

\section{REFERENCES}

Agra MF (2008). Survey of medicinal plants used in the region Northeast of Brazil. J. Pharmacol. 18:472-508.

Agripino DG, Lima MEL, Silva MR, Meda Cl, Bolzani VS, Cordeiro I, Young MCM, Moreno PRH (2004). Screening of Brazilian plants for antimicrobial and DNA-damaging activities. I. Atlantic rain forest. Ecological Station Juréia-Itatins. Biota. Neotrop. 4:1-15.

Barbosa WLR, Quignard E, Tavares ICC, Pinto LN, Oliveira FQ, Oliveira RM. (2004). Manual para Análise Fitoquímica e Cromatográfica de Extratos Vegetais. Rev. Cien. UFPA. 4.

Bednarczuk VO, Verdam MCS, Miguel MD, Miguel OG (2010). Tests in vitro and in vivo used in the toxicological screening of natural products. Vis. Acad. 11:43-50.

Biso FI, Rodrigues CM, Rinaldo D, Reis MB, Bernardi CC, De Mattos JCP, Caldeira-de-Araujo A (2010). Assessment of DNA damage induced by extracts fractions and isolated compounds of Davilla nitida and Davilla elliptica (Dilleniaceae). Mutat. Res. 702:92-99.

Boubaker J, Ghedira Z, Ghedira K, Chekir-Ghedira L (2013). Antigenotoxic and antioxidant activity in human chronic myelogenous leukaemia cell line K562 enhanced by Nitraria retusa leaf extracts. Cell Biol. Int. Rep. 20:5-12.

Brunetti C, Ferdinando MD, Fini A, Pollastri S, Tattini M (2013). Flavonoids as Antioxidants and Developmental Regulators: Relative Significance in Plants and Humans. Int. J. Mol. Sci. 14:3540-3555.

Caldeira-de-Araujo A, Dantas FJS, Moraes MO, Felzenszwalb I, Bernardo-filho M (1996). Stannous chloride participates in the generation of reactive oxygen species. J. Braz. Assoc. Adv. Sci. 48:109-113

Chaabane F, Boubaker J, Loussaif A, Neffati A, Kilani-Jaziri S, Ghedira K, Chekir-Ghedira L (2012). Antioxidant, genotoxic and antigenotoxic activities of Daphne gnidium leaf extracts. Complement. Altern. Med. 12:1-10.

De Mattos JCP, Dantas FJS, Caldeira-de-Araújo A, Moraes MO
(2004). Agarose gel electrophoresis system in the classroom: detection of DNA strand breaks through the alteration of plasmid topology. Biochem. Mol. Biol. Educ. 32:254-257.

Dragan S, Andrica F, Serban, MC, Timar R (2015). Polyphenols-Rich Natural Products for Treatment of Diabetes. Curr. Med. Chem. 22:1422.

Düsman E, Berti AP, Soares LC, Vicentini VEP (2012). The main mutagens and carcinogens agents of human exposure. Rev. Saúd. Biol. 7:66-81.

Efferth T, Greten HJ (2012). Quality Control for Medicinal Plants. Med. Aromat. Plants. 1:e131.

Efferth T, Greten HJ (2014). Traditional Medicine with Plants - Present and Past. Med. Aromat. Plants. 3:e151.

Ferreira G (1995). Estudo taxonômico das espécies brasileiras do gênero Norantea Aublet (Marcgraviaceae). Arq. Jard. Bot. 33:9-53.

Ferreira-Machado SC, Rodrigues MP, Nunes APM, Dantas FJS, De Mattos JCP, Silva CR (2004). Genotoxic potentiality of aqueous extract prepared from Chrysobalanus icaco L. leaves. Toxicol. Lett. 151:481-487

Giraldo-Cañas D (2004). Las especies del género Schwartzia (complejo Norantea, Marcgraviaceae) en Brasil. Darwiniana. 42:169-175.

Gurib-Fakim A (2006). Medicinal plants: Traditions of yesterday and drug of tomorrow. Mol. Aspects Med. 27:1-93.

Hamedt AL, Ortiz IC, Garcia-Huertasa PA, Sáenzc J, Caldeira-DeAraujo A, De Mattos JCP, Rodríguez-Gasqueze MA, Triana-Chávez O (2014). Cytotoxic, mutagenic and genotoxic evaluation of crude extracts andfractions from Piper jericoense with trypanocidal. Acta Trop. 131:92-97.

Jachak SM, Saklani A (2007). Challenges and opportunities in drug discovery from plants. Curr. Sci. 92:1251-1257.

Jones NP, Arnason JT, Aboud-zaid M, Akpagana K, Sanchez-Vinda P, Smith ML (2000). Antifungal activity of extracts from medicinal plants used by first nations peoples of Eastern Canada. J. Ethnopharmacol. 73:191-198.

Mello GS, Ignacio ACPR, Albarello N (2014). Potencial antibacteriano de Schwartzia brasiliensis. Novas Edições Acadêmicas. OmniScriptum GmbH \& Co. Saarbrüken, Deutschland. 52 p.

Mello GS, Moraes BA, Sá AF, Vilardo AF, Rocha AS, Cordeiro LS, Simões-Gurgel C, Albarello N (2012). Estudos fitoquímicos e de toxicidade de Cleome rosea e Norantea brasiliensis cultivadas in vivo e in vitro. Anais do II Simpósio Flora das Restingas Fluminenses; fitoquímica e bioatividade.

Mullally M, Kramp K, Cayer C, Saleem A, Ahmed F, Mcrae C, Baker J, Goulah A, Otorola M, Sanchez P, Garcia M, Poveda L, Merali Z, Durst T, Trudeau VL, Arnason JT (2011). Anxiolytic activity of a supercritical carbon dioxide extract of Souroubea sympetala (Marcgraviaceae). Phytother. Res. 25:264-270.

Newman DJ, Cragg GM (2012). Natural Products as Sources of new drugs over the 30 Years from 1981 to 2010. J. Nat. Prod. 75:311-335.

Obrenovich ME, Nair NG, Beyaz A, Aliev G, Reddy P (2010). The role of polyphenolic antioxidants in health, disease and aging. Rejuvenation Res. 13:1-13.

Obrenovich ME, Li Y, Parvathaneni K, Yendluri BB, Palacios $\mathrm{HH}$ Leszek J, Aliev G (2011). Antioxidants in health, disease and aging. CNS Neurol. Disord. Drug Targets 10:192-207.

Olasehinde $\mathrm{GI}$, Ojurongbe $\mathrm{O}$, Adeyeba AO, Fagade OE, Valecha $\mathrm{N}$, Ayanda, IO, Ajayi AA, Egwari LO (2014). In vitro studies on the sensitivity pattern of Plasmodium falciparum to anti-malarial drugs and local herbal extracts. Malaria J. 13:1-7.

Procházková D, Boušová I, Wilhelmová N (2011). Antioxidant and prooxidant properties of flavonoids. Fitoterapia 82:513-523.

Remington RD, Schor MA (1985). Some important distributions. In Johnson RA, Wichem DW (Ed.), Statistics with Applications to the Biological and Health Sciences. Prentice-Hall, Inc., Englewood Cliffs: New Jersey. 415p.

Rocca MA, Sazima M, Sazima I (2006). Woody woodpecker enjoys soft drinks: the blond-crested woodpecker seeks nectar and pollinates canopy plants in South-Eastern Brazil. Biota Neotrop. 6:1-9. 
Rocca MA, Sazima M (2008). Ornithophilous canopy species in the Atlantic rain Forest of southeastern Brazil. J. Field Ornithol. 79:130137.

Romano B, Pagano E, Montanaro V, Fortunato AL, Milic N, Borelli F (2013). Novel Insights into the Pharmacology of Flavonoids. Phytother. Res. 27:1588-1596.

Simões C, De Mattos JCP, Sabino KCC, Caldeira-De-Araújo A, Coelho MGP, Albarello N, Figueiredo SFL (2006). Medicinal potential from in vivo and acclimatized plants of Cleome rosea. Fitoterapia. 77:94-99. Zamith LR, Scarano FR (2004). Seedlings of species of Restingas the city of Rio de Janeiro, RJ, Brazil. Acta Bot. Bras. 18:161-176. 